\title{
The State-of-the-Art Treatments for Brain Tumors using Cell Atlas and Artificial Intelligence
}

\author{
Atsushi Natsume, M.D., Ph.D. \\ Department of Neurosurgery, Nagoya University School of Medicine
}

There are approximately 40 trillion cells in a human body. Were the DNA contained in each of these cells to be connected end-to-end, it would measure 74 billion kilometers, amounting to the distance from Earth to Sirius. Analysis of this length of DNA is now possible within a period as short as a few hours. Since the mid-2000s, next-generation sequencing (NGS) has become widely available, and we have now reached the era of the $\$ 1000$ genome with which NGS platforms have been completed. Intron-reading whole genome sequencing (WGS) technology is now mainstream, replacing the use of targeted gene sequencing panels. By 2020, we should expect that WGS analysis will become standard over DNA analysis using panel-based NGS or exon sequencing. WGS is now also capable of rapidly screening millions of genetic abnormalities with the advent of artificial intelligence (AI), such as the representative AI,"Watson for Genomics”. In an era with such an abundance of electronic data and overwhelming amounts of published scientific literature, particularly research related to glioma, Watson for Genomics can help scientists more efficiently learn, analyze, and draw conclusions from information contained in 20 million papers on a daily basis, covering topics such as cancerous mutations and the mechanisms of the human body. Information related to genetic mutations can then offer insight into determining the most appropriate therapeutics. Further, the "Human Cell Atlas", a project aiming to cultivate better understanding of the actions of individual cells in a variety of contexts such as cancer biology, neuroscience, and developmental biology, has now commenced. Within the biological central dogma comprised of the genome, the cell, and the body, medicine will likely evolve rapidly in the coming $2-3$ years.

(Received August 30, 2018; accepted September 19, 2018)

Key words : glioma, next genaration sequencing, single cell analysis, artificial intelligence

Jpn J Neurosurg（Tokyo）27:889-895, 2018

\begin{abstract}
緒 言
2000 年代にヒトゲノム解析が終焉し，あたかもヒトの ゲノムすべてが理解できたような錯覚があった。しか し，そこには個体差が多く存在し，各種疾患がゲノム異
\end{abstract}

常によって引き起こされることが明らかになるにつれ， 疾患特有のゲノム異常と進行度に関連した異常の蓄積, さらにそれらを標的とした分子標的治療が開発されてい る.

\footnotetext{
連絡先 : 夏目敦至, $\overline{\mathrm{T}} 466-8550$ 名古屋市昭和区鶴舞町 65 名古屋大学大学院医学系研究科脳神経外科

Address reprint requests to: Atsushi Natsume, M.D., Ph.D., Department of Neurosurgery, Nagoya University School of Medicine, 65 Tsurumai-cho, Showa-ku, Nagoya-shi, Aichi 466-8550, Japan
} 


\section{1,000 ドルゲノム時代の到来}

従来は塩基配列はサンガー法が用いられてきた。サン ガー法は，デオキシリボ核酸を用いて DNA ポリメラー ゼの伸長を止める chain terminator 法である。一方, 次世 代シークエンスは機種ごとに原理が異なっている，大き く分けて, 合成シークエンス法, パイロシークエンス法, リガーゼ反応シークエンシング法が用いられる。これら の方法によって塩基配列決定速度が飛躍的に高まった。 2003 年でのヒトゲノム計画で, ヒトのゲノムをすべて解 読したと大きな話題になったが，当時は従来方法により 13 年の歳月と 3 千億円の費用がかかった。 2007 年に次世 代シークエンス法を用いて初のヒトのゲノムが解読され たが，そのときはたった 2 カ月， 1 億 2 千万円程度で読 み切った。 その後, 次世代シークエンサーの技術の向上 とともに費用も安価になりつつあり，今後はヒト 1 人の ゲノム解読は 1 時間, 数万円 (1,000 ドル) でできるよう になるといわれている.

\section{癌ゲノム解析}

次世代シークエンサーの登場により塩基配列決定能力 が革新的に上がり, 癌研究に応用されている。多くの癌 は体細胞ゲノムの塩基配列の変化 (変異) や染色体の増 減が原因である。中には遺伝性腫瘍があり全身の細胞が 変異している場合もあるが，ほとんどは癌細胞だけの遺 伝子変化に留まっている.

しかし, 同じ癌種でも遺伝子変化が起こっている部分 が個人によって異なることが明らかになり，それを多く の患者で検討すると数個のタイプに大別されることが明 らかになってきた。したがって，同じ癌種でも，原因と なる遺伝子は異なり, 治療効果のある抗癌剂も異なるこ とになる.この次世代シークエンサーを用いた研究によ り, 癌の悪性度, 治療反応性, 予後などの指標となる遺 伝子変化が明らかになりつつある。この指標（バイオ マーカー）が得られれば，副作用が強く治療効果が期待 できない抗癌剤を避け，上り最適な抗癌剤が個別に採用 されることになる。

まず次世代シークエンスで，癌の原因遺伝子を見出す 方法は, エクソン（ゲノム上で最終的に成熟 mRNA とな る部分）部分のみを取り出してシークエンスすることで コストを $1 / 10$ にできる。これによってタンパク質構造 が変化するような変異を見出すことができる.

このように腫瘍の進展形式が明らかになり，治療抵抗 性や悪性化のメカニズムが解明され治療の発展につなが
ると考えられる。

\section{エクソンシークエンス}

エクソンシークエンスにおけるターゲット領域の濃縮 方法を Fig. 1 に示す。これはアジレント社の SureSelect の例であるが，アジレントは RNA ベイトを使用してい る。エクソン領域の配列に合わせた RNA ベイトはビオ チン化されており，ハイブリダイゼーションによりエク ソン領域のみを回収する（Fig. 1).

次世代シークエンサーのデー夕量は膨大であるため解 析にはスーパーコンピュータが必要である。リード長が 75〜200 bp のため，ヒトゲノムのリファレンス配列を使 用し，各リードを貼りつけていく作業を行う。そのため には高速度の処理を並列化して処理することのできる機 能が必要でありスーパーコンピュータが必須となってい る。東京大学情報基盤センターのハードディスクは 4.6 ベタバイト，計算能力は 225 テラフロップス，ジョブ処 理数は年間あたり 2,340 万ジョブであるが，昨今のニー ズ増大により，許容量を越えそうである。

変異を同定する手法はいくつか公開されている。その うちのひとつである EBCall は東京大学医科学研究所で 開発された。この手法はシークエンサーによるエラーを 効率よく排除するために, 複数の正常検体のシークエン スデー夕を使用するのが特徴である。シークエンスの精 度は，Depthと Coverage という用語を使う。Depth は 1 カ所の領域に結合する総リード数の平均で，エキソーム であれば 100〜150くらいで読むことが多い. Depthが高 ければ低アレル頻度の変異を同定できる。

Coverage は標的とした領域の何\%をカバーできたか を示す。コスト削減のために，いくつかのサンプルを pool することが多い. ハイブリダイゼーションの前に pool する pre-pool，ハイブリダイゼーションの後に pool する post-poolがある. Pre-poolのほうが先にサンプルを 混ぜるため，以後の手技が楽になりコストも安いことに なる。

しかし, post-pool のほうがデー夕の質は高い。一方， pre-pool では八イブリダイゼーションに持ち込む 1 サン プルあたりの DNA 量が pool 数に応じて減少するため DNAの多様性が減少する。つまりいくら深くシークエン スしても同じ DNA 断片を読むことになり duplicate が増 えてしまうことが欠点である。 


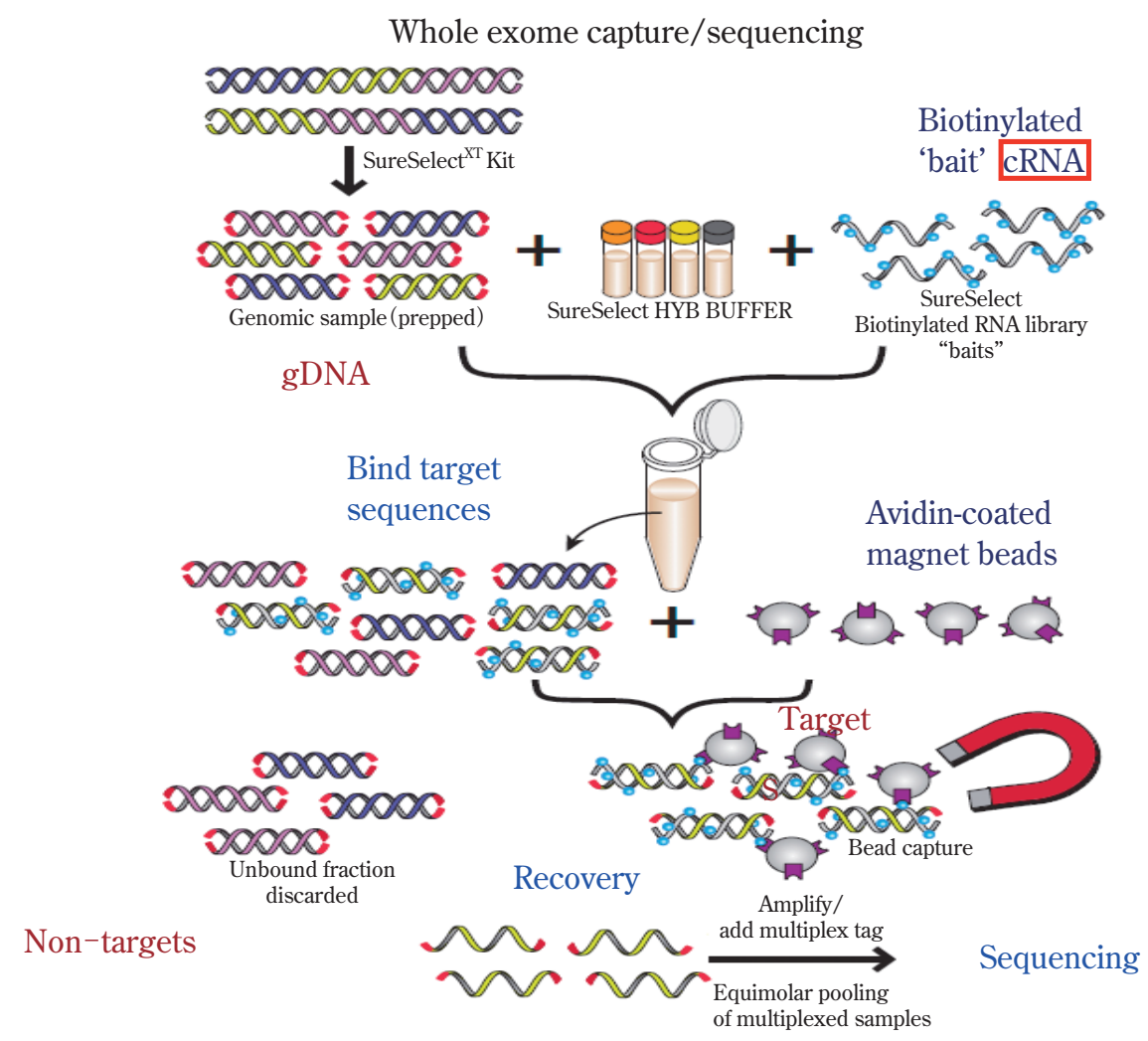

Fig. 1 Target enrichment methodology

Target enrichment methodology in exon sequencing is shown in Fig. 1, depicting an example of the Agilent SureSelect model using a RNA bait. RNA bait corresponding to the exonic regions are biotinylated, and hybridization to these regions is leveraged to specifically analyze exonic regions.

\section{次世代シークエンサーとスーパーコンピュー タによる脳腫瘍の遺伝子異常の解明}

同じ藏器の癌でも患者が異なればその遺伝子異常は異 なるということはさまざまな腫瘍で明らかとなってい る。そのため, 遺伝子異常を解明するには多数の症例が 必要となる。日本国内 5 施設から合計 332 例の低悪性度 神経膠腫の DNA を採取し，次世代シークエンサーを用 いた網羅的遺伝子変異解析を行った。これらのデー夕に 加え，米国の The Cancer Genome Atlas が公開している 425 例のシークエンスデータも利用した。

2015 年, Suzuki ${ }^{10)}$ は低悪性度グリオーマから二次性 グリオブラストーマを形成する過程において, IDH1 遺 伝子異常が最も早く起こるイベントであることを明らか にした．多くの低悪性度グリオーマはまず IDH1 遺伝子 異常を獲得した後に, 他の遺伝子異常を獲得してアスト ロサイトーマ，オリゴデンドログリオーマとなってい く. IDH1 変異と 1p19q loss を示す Type 1(オリゴデンド ログリオーマ) は, IDH1 変異と TP53 遺伝子異常を獲得
した Type 2（アストロサイトーマ）と比較して有意に予 後がよいことが明らかになった（Fig. 2)。大変興味深い ことに従来の WHO グレード 2,3 のグリオーマをまとめ て，1p/19q 共欠失の有無で分類することにより，WHO グレード（グレード 2，3）よりも正確に予後を予測する ことができた。低悪性度グリオーマ（グレード2）と退 形成性グリオーマ (グレード3) をまとめて lower grade glioma とし，遺伝子異常により正確に悪性度診断をする ことができることが明らかになった。興味深いことに IDH1 変異を有さない Type 3 は原発性グリオブラストー マに近い遺伝子異常パターンを示し，予後も比較的原発 性グリオブラストーマに近いことが明らかになった。今 後は IDH1 変異に依存しない, Type 3 lower grade glioma の腫瘍形成メカニズムの解析が待たれる.

\section{癌エピゲノム解析}

癌ゲノム解析が進み，エピゲノムを調節する遺伝子に 多数の不活化の変異を認めることがわかってきた。この 


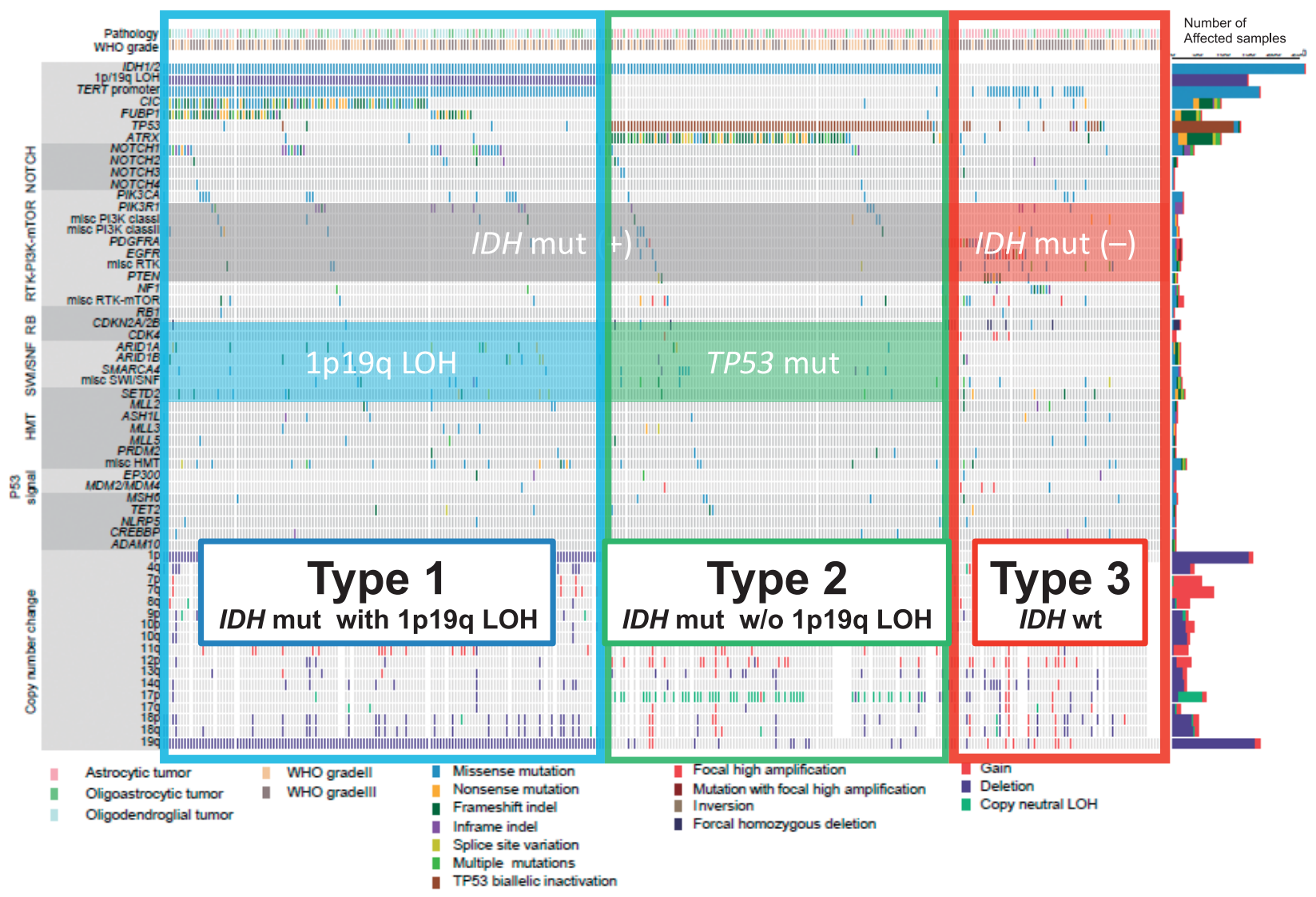

Fig. 2 Three genotypes in lower-grade gliomas

A large proportion of benign gliomas must first acquire genetic aberrations in the IDH1 gene before acquiring other genetic aberrations to transform into astrocytoma and oligodendroglioma. Mutation of the IDH1 gene and 1p19q loss marks Type 1 gliomas (oligodendrogliomas), which have better prognosis in comparison to Type 2 gliomas (astrocytomas), characterized by IDH1 mutation and TP53 genetic aberrations.

変異によってエピゲノム（DNAメチル化，ヒストン修飾 や非翻訳 RNA の発現）に変化が生じ，それが遺伝子の 異常な発現につながっている ${ }^{11}$ 。つまりゲノムとエピゲ ノムの変化は独立した事象ではなく, 互いに関連しクロ ストークしていると考元られる。このエピゲノムの異常 は非可逆的なゲノム異常とは異なり可逆的であるため近 年, 治療の夕ーゲットとしても注目され, 急速に解析が 進んでいる（Fig.3）.

\section{DNA メチル化解析}

癌の特徵的なエピゲノム異常のひとつにDNAのメチ ル化による転写制御の異常がある。実際に, グリオーマ においては, 若年で比較的予後がよいといった特徵をも つDNAの異常な高メチル化を示す群が存在する7). また MGMT 遺伝子の DNA メチル化はグリオーマ抗癌剤の効 果予測因子とされ, 実臨床にて必須の検査項目となって いる ${ }^{4)}$.
DNA のメチル化を解析するためには，まずメチル化 DNA を検出する必要がある。これには, (1)バイサルファ イト法（バイサルファイト処理によりメチル化されてい ないシトシンはウラシルに変わり，メチル化されたシト シンはそのまま残る。つまりメチル化の有無によって異 なつた塩基配列になることを利用する)，(2)制限酢素法 (メチル化された塩基の種類および位置によってDNAを 切断できなくなる制限酵素の特徵を利用する), (3) ル化親和性タンパク質による DNA 濃縮（断片化した DNA とメチル化 DNA 親和性タンパク質を結合させメチ ル化 DNA のみ濃縮する方法）がよく用いられる.

ゲノムDNAの目的領域が決まっている場合は(1)，(2) の方法, 網羅的な解析を行う場合には(3)の方法が用いら れることが多い. 次に, (1)〜3で収集した DNAを研究 の目的に応じて解析する. 特定の遺伝子領域の DNA メ チル化を定量するためにはリアルタイム PCR (methylation-specific PCR) やシーケンサー (パイロシークエンス 


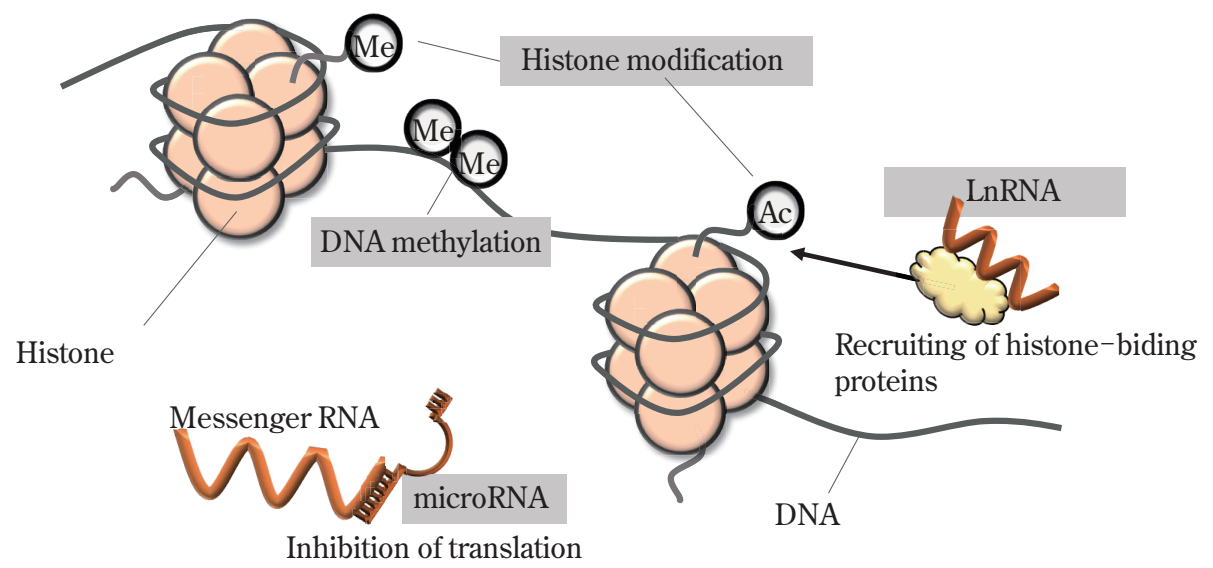

Fig. 3 Epigenome regulation

Genes controlling the epigenome show large amount of inactivating mutations. These mutations cause changes in the epigenome (i. e. DNA methylation, histone modification, and expression of non-coding RNA) and are linked to the aberrant expression of specific genes.

法）を用いて解析する。 またゲノムワイドに網羅的な解 析を行う場合にはマイクロアレイや次世代シーケンサー を用いて解析する。網羅性, 定量性, 経済性, 簡便性を 考えて適切な方法を選ぶ必要がある。

\section{ChIP on Chip と ChIP-seq}

DNA はヒストンというタンパク質に巻き付いて核内 に存在する.このヒストンへの化学修飾（メチル化, ア セチル化など）もエピゲノムのひとつで, この異常に よってヌクレオソームの構造が変化し, 遺伝子の転写調 節異常が起こる1). 実際に, グリオーマにおいては, 七 ストンをコードする遺伝子異常（H3F3A）を生じる一群 が存在し，それらは幼児期や青年期に正中部に発生する 特徵をもつ ${ }^{9}$.

異常な化学修飾を受けているヒストンが巻きついてい る DNA の領域を網羅的に調べる方法が ChIP on Chip ま たは ChIP-seq である。“ChIP” はクロマチン免疫沈降法 (chromatin immunoprecipitation) の略, “chip” はマイク ロアレイを指し, “seq”は次世代シークエンスを指す。

つまりヒストン修飾酵素で免疫沈降した DNA ChIP on Chip ではマイクロアレイで, ChIP-seqでは次世代シー ケンサーで解析する手法である。具体的には, DNA 結合 タンパク質と DNA を架橋結合した後に, クロマチンを 断片化し，目的とするヒストン修飾醭素に対する特異的 な抗体による免疫沈降を行う。その後, 架橋結合を解除 し，DNA を回収する. ChIP on Chip では回収した DNA を必要量まで PCRで増幅し, 蛍光標識試薬で標識の後, マイクロアレイにハイブリダイゼーションする。また
ChIP-seqではさらに断片化した後に両末端にアダプ ターを付加し PCR で増幅し, シークエンスする. ChIPseq は ChIP on Chip に比べて短い配列を取得するため感 度や解像度が優れ, さらに少量のサンプルで解析できる ことがメリットとされている.

\section{RNA シークエンシング (RNA-Seq)}

ヒトゲノムの $80 \%$ 以上は RNA に転写されるが，その 中でタンパク質に翻訳されるものは $2 \%$ 以下であり大多 数は翻訳されない RNA（non-coding RNA：ncRNA）であ る ${ }^{3)}$. 18〜24 塩基からなるマイクロ RNA と 200 塩基以上 からなる長鎖非翻訳 RNA などの ncRNA はエピゲノム調 節や他の RNA との相互作用などの生物学的活性を介し て癌に関連することがわかってきた ${ }^{6)}$ 。実際に, microRNA-211 ${ }^{11)}$ や TUG $1^{5)}$, ECONEXIN $^{2)}$ といった ncRNA がグリオーマ形成や増殖に関わると報告されて いる.

これら ncRNA の機能を解析するためにはその発現量 を計測する必要がある。かつては特定の RNA 発現量の 測定にマイクログラム単位の RNA を使用したノーザン ブロット法が行われた。その後, PCR が普及するに伴っ てナノグラム単位の RNA を使用したリアルタイム PCR 法が開発され, 現在でも広く用いられている. 時代は進 み, 次世代シーケンサーを用いた RNA シークエンシン グが登場しゲノムワイドな RNAの発現解析が可能な時 代となった。 RNA シークエンシングでは $1 \mathrm{ng}$ の total RNAがあれば解析を行うことが可能になった。 TCGA プ ロジェクトの後の Human Cell Atlas プロジェクトでは, 
1 細胞でのイメージングおよびRNA-Seqが行われるよう になっている ${ }^{8)}$.

\section{今後の方向性}

上記のような技術革新を受けて, 臨床の現場でもゲノ 么解析を行い, 適切な個別化医療を模索するプロジェク ト（がんゲノム医療中核拠点）が立ち上がった。現在の ところ，全エクソンシーケンス，もしくは 100 個以下の み遺伝子変異を調べるターゲットパネルが行われてい る.しかし，上記のように非翻訳 RNAの解析やプロモー 夕ー領域の変異解析を行うには不十分であり, 全ゲノム 解析に数年以内に移行していくと考元られる。 ある患者 で検出される変異は約 1,500 遺伝子あり, そのうち遺伝 的個性・多様性（SNP）は 1,400 遺伝子, したがって有 用な遺伝子は数 10 個程度である. 近年加速度的に増加 する研究論文, 臨床試験の論文の中から, エビデンスレ ベルの高い情報を抽出する作業がとてつもなくボトル ネックとなっている。 そのため, IBM Watson for Genomics のような人工知能の活用が必須となってくる。この ようなサービスを提供する企業も増えてきていて, アカ デミアと中核拠点と企業が共同して進めていく必要があ る。

\section{COI}

著者は日本脳神経外科学会への COI 自己申告の登録を完了 しています，本論文に関して開示すべきCOI はありません．

\section{文 献}

1) Dawson MA, Kouzarides $T$ : Cancer epigenetics: from mechanism to therapy. Cell $\quad \mathbf{1 5 0}: 12-27,2012$.

2) Deguchi S, Katsushima K, Hatanaka A, Shinjo K, Ohka F, Wakabayashi T, Zong H, Natsume A, Kondo Y : Oncogenic effects of evolutionarily conserved noncoding RNA ECONEXIN on gliomagenesis. Oncogene $36:$ 4629-4640, 2017.

3) Djebali S, Davis CA, Merkel A, Dobin A, Lassmann T, Mortazavi A, Tanzer A, Lagarde J, Lin W, Schlesinger F, Xue C, Marinov GK, Khatun J, Williams BA, Zaleski C, Rozowsky J, Röder M, Kokocinski F, Abdelhamid RF, Alioto T, Antoshechkin I, Baer MT, Bar NS, Batut P, Bell K, Bell I, Chakrabortty S, Chen X, Chrast J, Curado J, Derrien T, Drenkow J, Dumais E, Dumais J, Duttagupta R, Falconnet E, Fastuca M, Fejes-Toth K, Ferreira P, Foissac S, Fullwood MJ, Gao H, Gonzalez D, Gordon A, Gunawardena H, Howald C, Jha S, Johnson R, Kapranov P, King B, Kingswood C, Luo OJ, Park E, Persaud K, Preall JB, Ribeca P, Risk B, Robyr D, Sammeth M, Schaffer L, See LH, Shahab A, Skancke J, Suzuki AM, Takahashi H, Tilgner H, Trout D, Walters N, Wang H, Wrobel J, Yu Y, Ruan X, Hayashizaki Y, Harrow J, Gerstein M, Hubbard T, Reymond A, Antonarakis SE, Han- non G, Giddings MC, Ruan Y, Wold B, Carninci P, Guigó R, Gingeras TR: Landscape of transcription in human cells. Nature 489: 101-108, 2012.

4) Hegi ME, Diserens AC, Gorlia T, Hamou MF, de Tribolet N, Weller M, Kros JM, Hainfellner JA, Mason W, Mariani L, Bromberg JE, Hau P, Mirimanoff RO, Cairncross JG, Janzer RC, Stupp R: MGMT Gene Silencing and Benefit from Temozolomide in Glioblastoma. N Engl J Med 352: 99710032005.

5) Katsushima K, Natsume A, Ohka F, Shinjo K, Hatanaka A, Ichimura N, Sato S, Takahashi S, Kimura H, Totoki Y, Shibata T, Naito M, Kim HJ, Miyata K, Kataoka K, Kondo Y : Targeting the Notch-regulated non-coding RNA TUG1 for glioma treatment. Nat Commun $7: 1616,2016$.

6) Kotake Y, Nakagawa T, Kitagawa K, Suzuki S, Liu N, Kitagawa M, Xiong Y : Long non-coding RNA ANRIL is required for the PRC2 recruitment to and silencing of p15 (INK4B) tumor suppressor gene. Oncogene $30: 1956^{-}$ 1962, 2010.

7) Lai A, Kharbanda S, Pope WB, Tran A, Solis OE, Peale F, Forrest WF, Pujara K, Carrillo JA, Pandita A, Ellingson BM, Bowers CW, Soriano RH, Schmidt NO, Mohan S, Yong WH, Seshagiri S, Modrusan Z, Jiang Z, Aldape KD, Mischel PS, Liau LM, Escovedo CJ, Chen W, Nghiemphu PL, James CD, Prados MD, Westphal M, Lamszus K, Cloughesy T, Phillips HS : Evidence for sequenced molecular evolution of IDH1 mutant glioblastoma from a distinct cell of origin. J Clin Oncol 29: 4482-4490, 2011.

8) Patel AP, Tirosh I, Trombetta JJ, Shalek AK, Gillespie SM, Wakimoto H, Cahill DP, Nahed BV, Curry WT, Martuza RL, Louis DN, Rozenblatt-Rosen O, Suvà ML, Regev A, Bernstein BE : Single-cell RNA-seq highlights intratumoral heterogeneity in primary glioblastoma. Science $\mathbf{3 4 4}$ : 1396-1401, 2014.

9) Schwartzentruber J, Korshunov A, Liu XY, Jones DT, Pfaff E, Jacob K, Sturm D, Fontebasso AM, Quang DA, Tönjes M, Hovestadt V, Albrecht S, Kool M, Nantel A, Konermann C, Lindroth A, Jäger N, Rausch T, Ryzhova M, Korbel JO, Hielscher T, Hauser P, Garami M, Klekner A, Bognar L, Ebinger M, Schuhmann MU, Scheurlen W, Pekrun A, Frühwald MC, Roggendorf W, Kramm C, Dürken M, Atkinson J, Lepage P, Montpetit A, Zakrzewska M, Zakrzewski K, Liberski PP, Dong Z, Siegel P, Kulozik AE, Zapatka M, Guha A, Malkin D, Felsberg J, Reifenberger G, von Deimling A, Ichimura K, Collins VP, Witt H, Milde T, Witt O, Zhang C, CasteloBranco P, Lichter P, Faury D, Tabori U, Plass C, Majewski J, Pfister SM, Jabado N : Driver mutations in histone H3.3 and chromatin remodelling genes in paediatric glioblastoma. Nature 482: 226-231, 2012.

10) Suzuki H, Aoki K, Chiba K, Sato Y, Shiozawa Y, Shiraishi Y, Shimamura T, Niida A, Motomura K, Ohka F, Yamamoto T, Tanahashi K, Ranjit M, Wakabayashi T, Yoshizato T, Kataoka K, Yoshida K, Nagata Y, Sato-Otsubo A, Tanaka H, Sanada M, Kondo Y, Nakamura H, Mizoguchi M, Abe T, Muragaki Y, Watanabe R, Ito I, Miyano S, Natsume A, Ogawa S: Mutational landscape and clonal architecture in grade II and III gliomas. Nat Genet $\quad 47:$ 458-468, 2015.

11) Zhang J, Lv J, Zhang F, Che H, Liao Q, Huang W, Li S, Li Y : MicroRNA-211 expression is down-regulated and associated with poor prognosis in human glioma. J Neurooncol 133 : 553-559, 2017. 
シングル細胞レベルの Cell Atlas と Al を用いた脳腫瘍治療への展望

\section{夏目 敦至}

ヒトの細胞は約 40 兆個あり, 細胞の DNA をつなげると 740 億 $\mathrm{km}$ ある. 地球からシリウスまでの 距離に相当する. この長さのDNAをわずか数時間で解析できる時代になった. 2000 年代半ばから「次 世代シークエンス (Next Generation Sequencing：NGS)」が普及し, 1,000 ドルゲノムの時代を迎 え, プラットフォームが完成した. 今はイントロンまでを読み込む全ゲノム解析 (WGS) が主流とな り，パネル解析は間もなく終焉を迎える．2020 年にはパネルでもエクソンでもなく，WGS で解析す るのが通常という時代が到来する. 加えて人工知能（AI）の登場である.

WGS では数千〜数百万の遺伝子異常がみつかる. 代表的な Al は Watson for Genomics である. 電 子化知識は汇濫し, グリオーマ関連の論文をキャッチアップするだけでも膨大な時間がかかる. Watson は 2,000 万報を超える論文情報をはじめ, 癌の変異や生命のメカニズムに関する膨大な知識を 日々学び理解し推論する. 遺伝子変異情報を元に適切な薬剤の情報を与える.ささらに Human Cell Atlas の開始である. 癌, ニューロサイエンス, 発生などの分野でひとつひとつの細胞の挙動を明らか にしていくというプロジェクトである. ゲノム・細胞・そして個体というドグマの中で，医療はわず か 2〜3 年で激変しているだろう. 